\title{
Organizational Citizenship Behavior of Islamic Banks Through Meaning in Life and Meaning of Work
}

\author{
Heru Sulistyo \\ Department of Management Faculty of Economics Sultan Agung Islamic University \\ Jl. Raya Kaligawe km. 4 Semarang, 50112, Indonesia
}

\begin{abstract}
Keywords:

JobSatisfaction;

Meaning in Life;

Meaning of Work;

Organizational

Citizenship

Behavior

Islamic banking had a market share that is still low if compared with conventional banks, so it has a big challenge to improve the performance and competitive advantage. Employees who were willing to have extra work for their organization will lead to the improvement of their performance and their organization. Several studies have examined multiple factors that affect organizational citizenship behavior (OCB), but it was still slightly stressing on the importance of psychological aspects of meaning in life and meaning of work. The purpose of this study was to examine the importance of meaning in life and meaning of work factors in improving OCB in the organization. The sample in this study was employees of the Islamic banks in Central Java, amounted to 100 people. The data collections were conducted by using questionnaires and in-depth interviews. Meanwhile, to analyze the data, the structural equation model with Partial least squares software was used. The results of data analysis showed that meaning in life had a significant effect on satisfaction and organizational citizenship behavior. Meaning of work also had a significant effect on satisfaction and organizational citizenship behavior. An employee's job satisfaction significantly affects the improvement of organizational citizenship behavior.
\end{abstract}

Kata Kunci:

Kepuasan Kerja;

Meaning of Work;

Meaning in Life;

Organizational

Citizenship

Behavior

\section{ABSTRAK}

Perbankan Islam memiliki pangsa pasar yang masih rendah dibandingkan dengan perbankan conventional, sehingga memiliki tantangan yang besar untuk meningkatkan kinerja dan keunggulan bersaing. Karyawan yang bersedia bekerja ekstra bagi organisasi akan mendorong peningkatan kinerja karyawan maupun organisasi. Perilaku sukarela karyawan yang bebas dari sistem penghargaan formal dan melampaui peran yang seharusnya dilakukan sangat penting dalam organisasi. Beberapa studi telah menguji beberapa faktor yang memengaruhi organizational citizenship behavior (OCB) namun masih sedikit yang menekankan pada pentingnya aspek psikologi seperti meaning in life dan meaning of work. Tujuan dari penelitian ini adalah menguji pentingnya faktor meaning in life dan meaning of work dalam meningkatkan OCB organisasi. Sampel dalam penelitian ini adalah karyawan bank Islam di Jawa Tengah yang berjumlah 100 orang. Pengumpulan data dilakukan dengan menggunakan kuesioner dan wawancara mendalam. Analisis data yang digunakan menggunakan persamaan struktural dengan software Partial least square. Hasil analisis data menunjukkan bahwa meaning in life berpengaruh signifikan terhadap kepuasan dan organizational citizenship behavior. Meaning of work juga berpengaruh signifikan terhadap kepuasan dan organizational citizenship behavior. Kepuasan kerja seseorang karyawan berpengaruh signifikan terhadap peningkatan organizational citizenship behavior. 
Nowadays, the competition in the financial services industry is very high, so it will affect the performance of Islamic banks in Indonesia. The growth of Islamic bank asset, third party funds and financing in 2016 were estimated at 15 percent. The Islamic banks in Indonesia still face several constraints and barriers to their development, among others, lack of capital, competence human resources, and use of information and technology. The strategic challenge faced by Islamic banking is the ability to generate pace of financial product innovation and Islamic banking. The results of this study indicate that the competitiveness of Islamic banks is significantly lower than conventional banks (Risfandi, Husa, \& Asri, 2016). The era of competition today has already been in time-based competition, so the ability and competence of human resources is a key success factor that needs to be prepared to respond to these dynamics. The understanding and mastery of knowledge on Islamic banking and finance products should be owned by every Islamic bank employee. In addition, the willingness of employees to work extra workload exceeds the standards set by organization becomes an important part in improving performance. Several studies on antecedent OCB have been conducted by researchers including Lapierre \& Hackett (2007), Salami (2010), Avey, Palanski, \& Walumbwa (2011), Eatough et al. (2011). Metaanalytic studies by Lapierre \& Hackett (2007) demonstrate that more meticulous employees exhibit higher OCB levels and employees with higher levels of job satisfaction indicate more OCB. Salami (2010) also found that the strategy of dealing, compromising became a significant predictor of OCB. Avey, Palanski, \& Walumbwa (2011) found that ethical leadership was positively associated with OCB followers. While the analytical meta study of Eatough et al. (2011) found that the role of ambiguity and OCB role conflict had a negative impact on OCB. Chiaburu et al. (2011) concluded that openness and conformity have a stronger relationship with OCB than performance in roles.
Voluntary behavior that goes beyond the performance expected will give benefits to the organization, in particular, the increase in performance of Islamic banks in the face of the ASEAN economic community. Some studies on OCB have been conducted by many researchers including knowledge sharing and job attitudes (Teh \& Sun, 2012), organizational commitment (Mohamed \& Anisa, 2012), employee engagement (Kataria, Garg, \& Rastogi, 2013), organizational justice and LMX (Wan, 2011), and job enrichment (Davoudi \& Mehdi, 2013). Studies conducted by Nursyamsi (2013), OCB have a significant effect on improving employee performance. Some of these studies only focused more on knowledge and behavioral aspects in improving OCB but did not dig further about attitude and meaning in life and work.

The significance of meaningful work has been the concern of researchers for several years through the development of transformational leadership theory, organizational culture, and employee engagement (Lips-Wiersma \& Morris, 2009). Researchers are increasingly focused on meaning in work as an important factor in generating the performance and well-being of individuals and organizations (Nielsen et al., 2008; Arnold et al., 2007). According to May, Gilson, \& Harter (2004), rethinking about meaningfulness in work is seen as a method to encourage employee motivation and attachment to work. The study conducted by Maharaj \& Schlechter (2007) have examined the importance of meaning in life (MIL) and the meaning of work (MOW) in improving public accountant OCB in multinational organizations. The results indicated that there is significant correlation between MIL and MOW on OCB. The concept of MIL and MOW is a construct that is currently becoming the focus of research in the field of positive organizational behavior (Luthans, 2002) in improving the performance of employees and organizations that emphasize on positive character. Someone who truly understands the life and work will tend to be easier to obtain satisfaction 


\section{Jurnal Keuangan dan Perbankan | PERBANKAN}

Vol. 21, No. 4, Oktober 2017: 630-640

in his work and is willing to carry out the work beyond the required standard of the organization. As an organization that is based on religious values and spirituality, the role of meaning in life and the meaning of work in improving the $\mathrm{OCB}$ of Islamic bank will be easily implemented more properly. The purpose of this study is to examine the effect of meaning in life and the meaning of work on satisfaction and organizational citizenship behavior.

\section{HYPOTHESES DEVELOPMENT}

\section{Organizational Citizenship Behavior}

Organ et al. (2005) defines OCB as discretionary behavior, indirectly or explicitly recognized by the formal reward system, and that in the aggregate promotes the effective functioning of an organization. Sahertian (2008) defines OCB as a worker's behavior that exceeds his formal duties and exceeds responsibility and contributes to organizational effectiveness. OCB is an individual behavior explicitly not recognized by the formal reward system, and aggregately promotes efficient and effective organizational functioning

According to Podsakoff et al. (2000), OCB has 7 dimensions: (1) helping behavior, it is a form of employee behavior that helps co-workers or avoids some incidents related to the problem of work; (2) sportsmanship, it is a desire to tolerate work that cannot be avoided or disturbances that exist without any problems; (3) organizational loyalty, it is promoting the organization to outsiders, protecting, and defending it against threats from outside and remaining committed even in adverse conditions; (4) organizational compliance, it is internalization and acceptance of the rules, regulations and procedures that exist in the organization although no controlling party; (5) individual initiative, it is the behavior to be involved in the task, the work for the continuity of the company of more than expected, or at the level of volun- teering; (6) civic virtue, it is the willingness to actively participate in the organization; and (7) selfdevelopment, it is a voluntary behavior to improve the knowledge, skills, and abilities.

\section{The Meaning in Life}

Frankl (1967) found that meaning in life is a human virtue which is motivated by the search for meaning in life, which is called as the desire for meaningful. Meaning that someone attach to life is a sign of being human and is connected with the spiritual side (which should not be associated with religion) of human nature to search meanings. Meaning in life will significantly be revealed when someone asks about the purpose in the workplace, the contribution made whether significant or not, as well as something that can be left at the workplace. Virtue is the degree of a person's life that is described as the emotional feelings of the desire to what is accepted as the commitment and positive energy. Maharaj \& Schlechter (2007) also emphasizes that a meaningful life of an individual is an indication of the balance between work and life. Furthermore, experiencing meaning in life will lead to a feeling of fulfillment and satisfaction beyond the other aspects of life.

The explanation of the meaning in life by some of the theories that have been proposed above can be concluded that the meaning in life is when someone is looking for meaning in his life, has a purpose for his life, and feels his life is important to go through because he has the role of his life. The impact of meaning in life is to realize further balance and wellbeing in work and life. Wrzesniewski (2003) found that a person who has the meaning in life in his life has a higher level of job satisfaction than other colleagues who do not have the meaning in life. Furthermore, according to Dimitriades (2001), the meaning in life is positively related to mental health and performance results, which is then interpreted as a psychologi- 
cal empowerment and affect at work engagement, job satisfaction, organizational commitment, and OCB. A person who has the meaning in life would have life balance and well-being at work, thus impacting positively on job satisfaction. When an employee is satisfied with the job, it will certainly encourage him to engage in work and organization, and be willing to perform extra roles (Organizational Citizenship Behavior). The study conducted by Maharaj \& Schlechter (2007) concluded that the meaning in life has a significant effect on satisfaction and OCB.

$\mathrm{H}_{1}$ : meaning in life effects on satisfaction

$\mathrm{H}_{2}$ : meaning in life effects on the organizational citizenship behavior

\section{Meaning of Work}

The study of meaning in work is driven by the assumption that the results and performance of employees and organizations are related to the perception of meaning in the work (Rosso, Dekas, \& Wrzesniewski, 2010). According to Sharabi (2017), the meaning of work is determined by individual experience in the organization and the environment in which they work and live. Meaning of work has 4 dimensions among them, centrality of work as a life role, valued work outcomes, importance of work goals, and work role identification. Kuchinke et al. (2008) using 4 dimensions meaning of work in his study, work centrality, valued work outcomes, work role identification, and social norms regarding work. Three psychological conditions that determine a person's motivation and job satisfaction are expressed by Hackman \& Oldham (1995), i.e., feeling the significance, one must accept a job as important as its value, feeling a responsibility, a person must believe that he must be responsible personally for the work he has done, and knowing the results of the work, the employee must be able to determine whether the results of his work is satisfactory or not. When these 3 things are fulfilled, it will contribute to a feeling of satisfaction on the job. The positive feelings will encourage someone further to continue to try to show performance at optimal levels. Meaning of work is derived from internal motivation and feeling the significance associated with the task and the work such as job satisfaction, work quality, and high performance. Harpaz (2002) suggested that the job makes a person feel meaningful in life. According to the study by Fox (1994), on meaning of work and job satisfaction has consistently maintained that workers who do not have the expertise tend to feel low job satisfaction. Meaning of work can be concluded as the way one views the job, if a job becomes very important or not for one's life. A work turns out to play an important role for the identity of a person, to have a positive self-identity that encourages positive self-esteem, so it will create a balanced life. Someone who has the meaning of work tend to know what to do on the job, so it can determine the steps that must be taken to perform tasks and work so that they can achieve the job satisfaction. Bolino, Turnley, \& Averett (2003) have shown that a person who has high job involvement in his work is more likely to show OCB. Organizations can improve the OCB by giving employees a meaningful job that will make them feel up to performance (i.e. job involvement or work engagement). Feeling important is associated with motivation and positive work attitudes by Sargent (1973). Bolino, Turnley, \& Averett (2003) statement is in line with the results of the study by Wrzesniewski (2003) which stated that a person with a significant feeling inclines to take the time and effort in his work and not rely on compensation given. Positive work attitude will arise when someone has the meaning of work, because he always wants to involve himself in any work as a result of the desire to achieve the higher purpose for his existence. The action of self-involvement is separated from the purpose of com- 
pensation, so it tends to have a proactive behavior such as OCB. The study conducted by Maharaj \& Schlechter (2007) concluded that the meaning of work has a significant effect on satisfaction and OCB.

$\mathrm{H}_{3}$ : meaning of work affects satisfaction

$\mathrm{H}_{4}$ : meaning of work affects the OCB

\section{Job Satisfaction}

According to Golbasi et al. (2008), job satisfaction is an emotional reaction and expression of the resulting performance based on one's judgment on the performance, the work environment, and work life. Job satisfaction is an emotional expression of employees as evaluations of the work, work environment, and the evaluation of expectations of what is obtained from the work and organization. Podsakoff et al. (2000) stated that OCB is affected by a positive work attitude. This is because employees are more likely to provide behavioral exceed role when they are satisfied with their jobs and committed to the organization (Bolino, Turnley, \& Averett, 2003). The study by Chiu \& Chen (2005) recommended the organization to improve employee intrinsic job satisfaction to encourage OCB. Research conducted by Jung \& Yoon (2015) found that job satisfaction has a significant effect on the improvement of OCB. Job satisfaction mediates the influence of psychological capital on OCB. A study conducted by Foote \& Tang (2008) found that employee job satisfaction has a significant effect on OCB. Research conducted by Nadiri \& Tanova (2010); Shokrkon \& Naami (2009); Swaminathan \& Jawahar (2013) also concluded that employee satisfaction can improve OCB. Gyekye \& Haybatollahi (2015) found that high levels of employee satisfaction will increase OCB. Employees who are satisfied in their work will have high OCB (Indarti et al., 2017).

$\mathrm{H}_{5}$ : job satisfaction affects the OCB

\section{METHODS}

The sample in this study was all employees of Islamic Bank in Central Java covering Bank Syariah Mandiri, Bank BNI Syariah, Bank Mega Syariah, Bank BTN Syariah, and Bank Niaga Syariah, amounted to 100 respondents. Sampling technique used was purposive sampling, i.e., permanent employees and having worked of more than 5 years. Data were collected by using questionnaire submitted to the directors of the Islamic Banks to be distributed to respondents based on predetermined criteria. After 2 weeks, a questionnaire that was collected in the respective leaders of the Islamic Bank was taken back for analysis.

The variable of meaning in life was measured by using 4 indicators, feeling meaningful, benefits for others, trying to find something that makes life meaningful, and trying to reach the goal of life. The variable meaning of work was measured by using indicators of centrality of work, valued work outcomes, work goals, and social norms. Job satisfaction was measured by using indicators of loving the job, interested in the job, and job suitability. Organizational citizenship behavior was measured by using indicators of altruism, conscientiousness, civic virtue, and sportsmanship. All indicators were measured by using likert scale of $1-5$, in which 1 is "strongly disagree" and 5 is "strongly agree".

Data analysis used is structural equation model by using approach of Partial Least Square (PLS). This approach is used because the estimation of latent variables in PLS is as exact linear combination of indicators, so as to avoid indeterminacy problems and produce appropriate component scores.

\section{RESULTS}

The description of each variable's average score was classified into 3 intervals, namely 'good' 
ranged between 3,68-5, 'fair' between 2,34-3,67, and 'low' between 1-2,33. The average scores and standard deviation of each variable were shown on Table 1 . The average scores of the variables meaning in life, meaning of work, job satisfaction, and OCB were classified into 'good' category.

During their work, the employees have determined their meaning of life in work and occured balance in their work and life. Besides, they also feel meaningful relationship between their duties and work results so that it would lead to good work satisfaction and OCB.

\section{Validity and Reliability Tests}

The validity test was conducted through using convergent validity method by PLS soft- ware. Convergent validity is a measurement model which describes the correlation between an indicator and its latent variables. The analysis result of this phase was outer loading score of each indicator and was considered to be valid if it results more than 0.5 or more.

Based on the result of validity test conducted, it is found that all indicators of the variables of meaning in life, meaning of work, satisfaction, and $\mathrm{OCB}$ resulted original sample estimate higher than 0,7 while $\mathrm{T}$ statistic score was higher than $\mathrm{T}$ table (1.67) which means that all indicators were valid and could measure their variables.

The reliability test was conducted through calculating composite reliability score of each variable. Based on Table 3, the result of composite reliability of each construct was more than 0.7.

Table 1. The Average Scores and Standard Deviation

\begin{tabular}{lcc}
\hline \multicolumn{1}{c}{ Variable } & Average & Standard Deviation \\
\hline Meaning in Life & 5.31 & 1.14 \\
Meaning of Work & 3.84 & 0.84 \\
Job Satisfaction & 4.19 & 0.44 \\
OCB & 4.38 & 0.61 \\
\hline
\end{tabular}

Table 2. The Result of Convergent Validity Test

\begin{tabular}{ccccc}
\hline & $\begin{array}{c}\text { Original Sample } \\
\text { Estimate }\end{array}$ & $\begin{array}{c}\text { The Mean of } \\
\text { Subsamples }\end{array}$ & $\begin{array}{c}\text { Standard } \\
\text { Deviation }\end{array}$ & T-Statistic \\
\hline Meaning in life & 0.927 & & & \\
$\mathrm{X}_{11}$ & 0.935 & 0.910 & 0.138 & 6.740 \\
$\mathrm{X}_{12}$ & 0.900 & 0.923 & 0.108 & 8.633 \\
$\mathrm{X}_{13}$ & 0.922 & 0.879 & 0.162 & 5.547 \\
$\mathrm{X}_{14}$ & & 0.907 & 0.108 & 8.528 \\
Meaning of work & 0.914 & & & \\
$\mathrm{X}_{21}$ & 0.933 & 0.914 & 0.019 & 49.139 \\
$\mathrm{X}_{22}$ & 0.922 & 0.936 & 0.016 & 57.077 \\
$\mathrm{X}_{23}$ & 0.901 & 0.925 & 0.017 & 52.824 \\
$\mathrm{X}_{24}$ & & 0.900 & 0.028 & 32.175 \\
Satisfaction & 0.851 & & & \\
$\mathrm{Y}_{11}$ & 0.886 & 0.856 & 0.042 & 20.215 \\
$\mathrm{Y}_{12}$ & 0.774 & 0.895 & 0.039 & 22.460 \\
$\mathrm{Y}_{13}$ & & 0.762 & 0.100 & 7.744 \\
$\mathrm{Y}_{21}$ & 0.912 & & & \\
$\mathrm{Y}_{22}$ & 0.876 & 0.914 & 0.022 & 41.635 \\
$\mathrm{Y}_{23}$ & 0.724 & 0.866 & 0.057 & 15.395 \\
$\mathrm{Y}_{24}$ & 0.741 & 0.703 & 0.128 & 5.673 \\
\hline
\end{tabular}

T Table Score: 1.67 
According to Chin (1998), an indicator is said to have good reliability if it has score more than 0.70 and can be approved on the scores of 0.50-0.60. The composite reliability scores of the variables of meaning in life 0.96 , meaning of work 0.95 , satisfaction 0.88 , and OCB 0.89 were more than 0.7 . The result of data analysis using Smart PLS software led to a finding that the inner model of the variables of meaning in life, meaning of work had an effect on satisfaction and OCB as on the Figure 1.

Based on the hypothesis test, it obtained original sample estimate score of meaning in life resulting 0.347 with the $t_{\text {count }}$ score (3.335) $>t_{\text {table }}$ (1.67), so that $\mathrm{H}_{1}$ was supported. There was a significant effect of meaning in life on work satisfaction, which means that the higher the level of employees in meaning their life, the easier in achieving satisfaction level in work. This finding also showed that the $\mathrm{H}_{2}$ was supported, the original sample estimate score resulted 0.282 with the $t_{\text {count }}$ score (2.044) $>t_{\text {table }}$ (1.67). The higher someone means his life, the higher his willingness to take extra roles. $\mathrm{H}_{3}$ was supported, original sample estimate score 0,549 with the $t_{\text {count }}$ score $(5.088)>t_{\text {tabel }}$ (1.67). Meaning in work had significant effect on work satisfaction, which means that the higher someone makes meaning of work in his organization, the higher he will acquire satisfaction. The test of $\mathrm{H}_{4}$ was supported, which means that there was significant effect of meaning of work on OCB, original sample estimate score resulted 0.435 with the $t_{\text {count }}$ score (2.989) $>t_{\text {table }}$ (1.67). The higher someone means a work in an organization, the higher his willingness to take extra roles. The result of $\mathrm{H}_{5}$ test was supported with original sample estimate score resulting 0.223 with the $t_{\text {count }}$ score

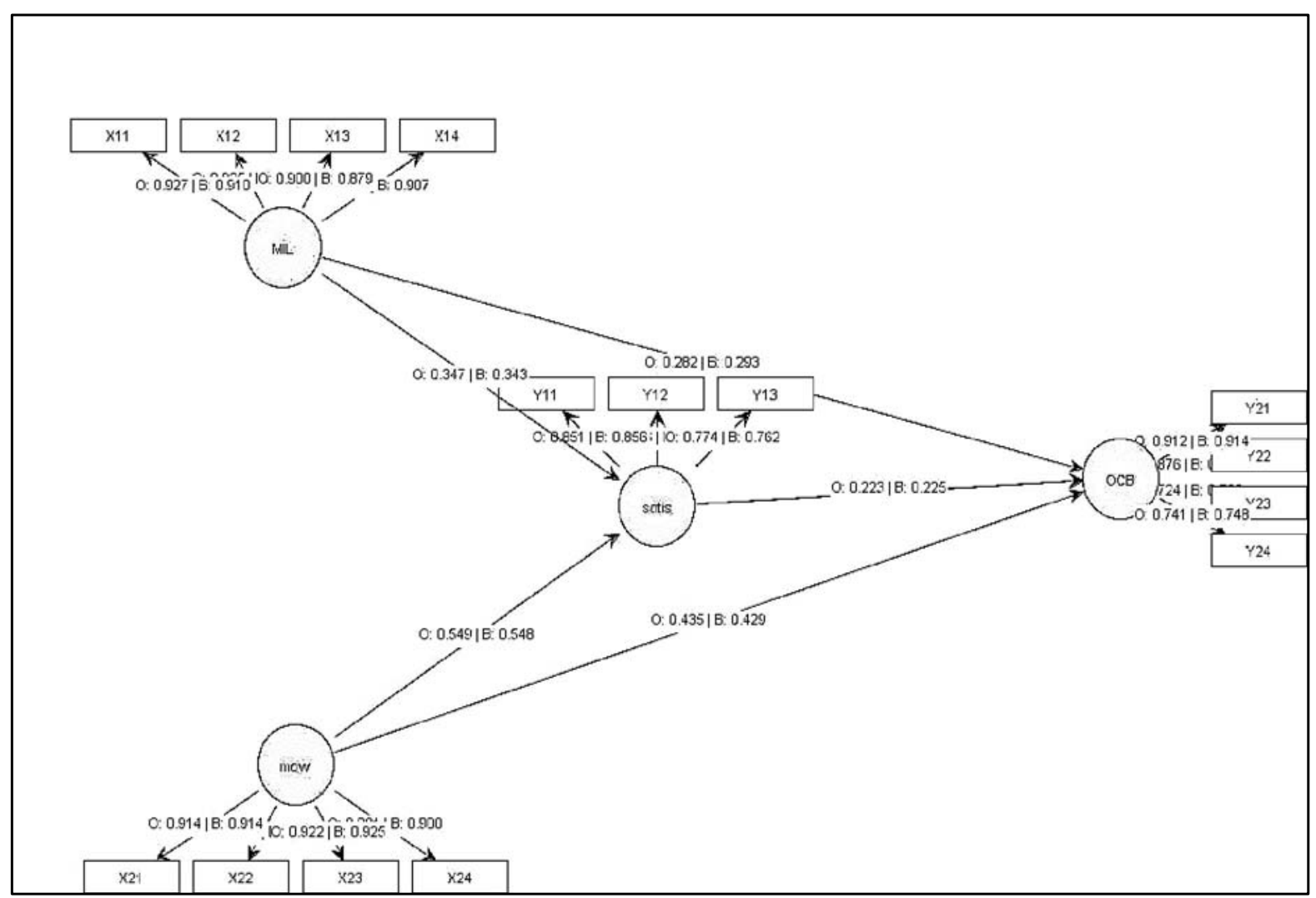

Figure 1. The Result of Inner Model 
$(1.709)>t_{\text {table }}(1.67)$, which means that there was significant effect of work satisfaction on OCB. The higher the level of someone's satifaction, the higher employees' potential availability in taking extra roles.

\section{DISCUSSION}

The finding of this study refers to the higher meaning in life, the higher work satisfaction will. It is in line with the study which was conducted by Wrzesniewski (2003) who found that someone with meaning in life has work satisfaction level higher than those who do not have it. The finding of Wrzesniewski (2003) is in line with the study which was conducted by Steger et al. (2006) who found that someone with meaning in life or feeling meaningful in life has lower level depression and feels more satisfied on his work and life, as well as shows higher levels of self-esteem and optimistic and other positive effects. Wrzesniewski (2003) found that an organization whose members have high meaning in life also reports an identification with stronger team, low work conflict, more honest and trust on governance, higher satisfaction on colleagues, more commitment on their organization, and has healthier group process. Maharaj \& Schlechter (2007) also explained further that someone's feeling that his life is meaningful is an indication of health and balance in his work and life. This condition later will lead to satisfaction feeling which is more than other aspects in life.

The finding also showed an effect of meaning in life on OCB. This finding is in line with the study which was conducted by Dimitriades (2001) who stated that meaning in life has positive effect on mental health and work result, where it is then referred as psychological empowerement which is also reported to lead to good work involvement, work satisfaction, organizational commitment, and over role behavior (OCB). Good meaning in life will have meaningful feeling by feeling beneficial for others. In line with that willingness, those efforts are implemented on over role behaviour which becomes a part of OCB.

The finding also showed that there was significant effect of meaning of work on work satisfaction. This finding is in line with the study which was conducted by Hackman \& Oldham (1995) that meaning of work begins from someone's internal motivation which is in line with other external factors such as work characteristics and the result of the work itself. This meaningful feeling has correlation with work such as work satisfaction, high work quality, and high performance. The finding also showed that meaning of work has significant effect on OCB. This study is in line with the study which was conducted by Wrzesniewski (2003) that someone with meaningful feeling tends to spare his time and effort on his work and does not rely on compensation given. Van Dyne, Graham, \& Dienesch (1994) stated that proactive behaviour such as OCB possibly will be followed by the increase of responsible and planted feelings in an organization. Positive work behaviour will appear when someone has meaning of work, because it always has self-involvement in every work as an effect of willingness to achieve desire in order to obtain higher purposes for self-existence. The results support the findings Maharaj \& Schlechter (2007), significant relationship was found between meaning in life and meaning of work toward job satisfaction and OCB.

The finding found that there was an effect of work satisfaction on OCB. This finding support the research done earlier by Nadiri \& Tanova (2010); Shokrkon \& Naami (2009); Swaminathan \& Jawahar (2013); Foote \& Tang (2008); Gyekye \& Haybatollahi, (2015), that employee satisfaction can improve OCB.

According to Podsakoff et al. (2000), that OCB is affected by positive work behaviour. This is because employees will tend to give extra role behaviour when they feel satisfied with their work 
and committed to their organization (Bolino, Turnley, \& Averett, 2003). The study conducted by Chiu \& Chen (2005) suggest that an organization to improve employees' intrisict job satisfaction in order to encourage OCB. The results support the study by Indarti et al. (2017), job satisfaction has a significant effect on OCB. Different research findings from Hakim \& Fernandes (2017), OCB moderate the effect of job satisfaction on performance. The results of the study differs from the findings of Shetach \& Marcus (2014), that citizenship behavior has a significant effect on satisfaction.

\section{CONCLUSION AND SUGGESTIONS}

\section{Conclusion}

This study aims to examine the importance of the factors of meaning in life and meaning of work in improving satisfaction and OCB. The finding showed that employees with high meaning in life and meaning of work will lead to high work satisfaction achievement and willing to take extra roles and finish their work without getting retaine of their organization. The managerial implication for an organization is that leader and management must always establish and strengthen organizational cultural values and employees' spiritual in order to have more meaning in life and meaning in work. The more ability of an organization to strenghten meaning in life and meaning of work of its employees, the easier to create employees' satisfaction, OCB, employees' performance, and organization's performance.

\section{Suggestions}

This study needs to be developed further in a religious based organization which has higher scope so that the effect of meaning in life and meaning of work will be stronger in affecting satisfaction and OCB. The roles of meaning in life and meaning of work in improving satisfaction and OCB still need to have strengthening or moderating variables to be added on. Further studies must also consider spiritual or religious aspect as a moderating variable. Managerial implications for sharia banking practitioners are that management must always maintain and strengthen the meaning in life and meaning of work of the employees through various spiritual activities such as emotional spiritual quotient training and strengthening the vision, mission, and objectives of sharia banking continuously in formal and informal activities. The implications for the development of science, the roles of meaning in life and meaning of work in improving satisfaction and OCB still need to have strengthening or moderating variables to be added on. Further studies must also consider spiritual or religious aspect as a moderating variable.

\section{REFERENCES}

Arnold, K. A., Turner, N., Barling, J., Kelloway, E. K., \& McKee, M. C. (2007). Transformational leadership and psychological well-being: The mediating role of meaningful work. Journal of Occupational Health Psychology, 12(3), 193-203.

Avey, J., Palanski, M., \& Walumbwa, F. (2011). When leadership goes unnoticed: The moderating role of follower self-esteem on the relationship between ethical leadership and follower behavior. Journal of Business Ethics, 98(4), 573-82.

Bolino, M. C., \& Turnley, W. H., \& Averett, T. (2003). Going the extra mile: Cultivating and managing employee citizenship behaviour. The Academy of Management Executive, 17(3), 60-73.

Chiaburu, D. S., Oh, I., Berry, C. M., Li, N., \& Gardner, R. G. (2011). The five-factor model of personality traits and organizational citizenship behaviors: A metaanalysis. Journal of Applied Psychology, 96(6), 114066.

Chin, W. W. (1998). The partial least squares approach for structural equation modeling in Marcoulides, G.A. (Ed). Modern method for business research. Marwah. NJ. Erlbaum. 


\section{Organizational Citizenship Behavior of Islamic Banks Through Meaning in Life and Meaning of Work}

Heru Sulistyo

Chiu, S. F., \& Chen, H. L. (2005). Relationship between job characteristics and organizational citizenship behaviour: The mediational role of job satisfaction. Social Behaviour and Personality: An International Journal, 33, 523-540.

Chou, S. Y., \& Pearson, J. M. (2012). Organizational citizenship behaviour in IT professionals: an expectancy theory approach. Management Research Review, 35(12), 1170-1186.

Davoudi, M., \& Mehdi, S. (2013). Impact: Job enrichment in organizational citizenship behaviour. SCMS Journal of Indian Management, 10(2), 106-112.

Dimitriades, Z., \& Kufidu, S. (2004). Individual, job, organizational, and contextual correlates of employement empowerment: Some Greek evidence. Electronic Journal of Business Ethics and Organization Studies, 9(2), 36-43.

Eatough, E. M., Chang, C., Miloslavic, S. A., \& Johnson, R.E. (2011). Relationships of role stressors with organizational citizenship behavior: A metaanalysis. Journal of Applied Psychology, 96(3), 61932.

Frankl, V. E. (1967). Psychotherapy and existentialism. London: Souvenir Press.

Foote, D. A., \& Tang, T. L. (2008). Job satisfaction and organizational citizenship behavior (OCB), does team commitment make a difference in self-directed teams? Management Decision, 46(6), 933-947.

Fox, M. (1994). The reinvention of work: A new vision of livelihood for our time. San Francisco: Harper Collins.

Golbasi, Z., Kelleci, M., \& Dogan, S. (2008). Relationships between coping strategies, individual characteristics and job satisfaction in a sample of hospital nurses: Cross-sectional questionnaire survey. International Journal of Nursing Studies, 45(12), 18001806.

Gyekye, S. A., \& Haybatollahi, M. (2015). Organizational citizenship behaviour: An empirical investigation of the impact of age and job satisfaction on Ghanaian industrial workers. International Journal of Organizational Analysis, 23(2), 285-301, https:// doi.org/10.1108/IJOA-08-2012-0586.

Hackman, J. R., \& Oldham, G. R. (1975). Development of the Job Design Survey. Journal of Applied Psychology, 60, 159-170.
Hakim, W., \& Fernandes, A. (2017). Moderation effect of organizational citizenship behavior on the performance of lecturers. Journal of Organizational Change Management, 30(7), 1136-1148.

Harpaz, I. (2002). Expressing a wish to continue or stop working as related to the meaning of work. European Journal of Work and Organizational Psychology, 11(2), 177-198.

Indarti, S., Solimun, Fernandes, A. A. R., \& Hakim, W. (2017). The effect of OCB in relationship between personality, organizational, commitment, and job satisfaction on performance. Journal of Management Development, 36(10), 1283-1293.

Jung, H. S., \& Hyun-Yoon, H. H. (2015). The impact of employees' positive psychological capital on job satisfaction and organizational citizenship behaviors in the hotel. International Journal of Contemporary Hospitality Management, 27(6), 1135-1156.

Kataria, A., Garg, P., \& Rastogi, R. (2013). Employee engagement and organizational effectiveness: The role of organizational citizenship behavior. International Journal of Business Insights $\mathcal{E}$ Transformation, 6(1), 102-113.

Kuchinke, K. P., Ardichvili, A., Borchert, M., \& Rozanski, A. (2008). The meaning of working among professional employees in Germany, Poland, and Russia. Journal of European Industrial Training, 33(2), 104-124.

Lips-Wiersma, M., \& Morris, L. (2009). Discriminating between 'meaningful work' and the 'management of meaning'. Journal of Business Ethics, 88(3), 491511

Luthans, F. (2002). The need for meaning of positive organizational behaviour. Journal of Organizational Behaviour, 23(6), 695-706.

Maharaj, I., \& Schlechter, A. F. (2007). Meaning in life and meaning of work: Relationships with organisational citizenship behaviour, commitment, and job satisfaction. Management Dynamics, 16(3), 24-42.

May, D. R., Gilson, R. L., \& Harter, L. M. (2004). The psychological conditions of meaningfulness, safety and availability and the engagement of the human spirit at work. Journal of Occupational and Organizational Psychology, 77(1), 11-37. 


\section{Jurnal Keuangan dan Perbankan | PERBANKAN}

Vol. 21, No. 4, Oktober 2017: 630-640

Mohamed, M. S., \& Anisa, H. (2012). Relationship between organizational commitment and organizational citizenship behavior. The IUP Journal of Organizational Behavior, 11(3), 7-22.

Nadiri, H., \& Tanova, C. (2010). An investigation of the role of justice in turnover intentions, job satisfaction and organizational citizenship behavior in hospitality industry. International Journal of Hospitality Management, 29(1), 33-41.

Nielsen, K., Randall, R., Yarker, J., \& Brenner, S.-O. (2008). The effects of transformational leadership on followers' perceived work characteristics and psychological well-being: A longitudinal study. Work and Stress, 22(1), 16-32.

Nursyamsi, I. (2013). Organizational citizenship behavior dan pemberdayaan. Jurnal Keuangan dan Perbankan, 17(3), 488-498.

Organ, D. W., Podsakoff, P. M., \& Mackenzie, S. B. (2005). Organizational citizenship behavior: Its nature, antecedents and consequences. Nursing Research, 53(5), 347-352.

Podsakoff, P. M., MacKenzie, S. B., Paine, J. B., \& Bachrach, D. G. (2000). Organizational citizenship behaviors: A critical review of the theoretical and empirical literature and suggestions for future research. Journal of Management, 26(3), 513-563.

Risfandi, T., Husa, P. P., \& Asri, H. (2016). Daya saing bank syariah di sebuah negara religius: Temuan empirik dari Indonesia. Jurnal Keuangan dan Perbankan, 20(2), 282-291.

Rosso, B. D., Dekas, K. H., \& Wrzesniewski, A. (2010). On the meaning of work: A theoretical integration and review. Research in Organizational Behavior, 30, 91127. doi:10.1016/j.riob.2010.09.001

Sahertian, P. (2008). Perilaku kepemimpinan berorientasi hubungan sebagai anteseden, self- efficacy dan organizational citizenship behavior. Jurnal Keuangan dan Perbankan, 12(2), 273-282.

Salami, S. O. (2010). Conflict resolution strategies and organizational citizenship behavior: the moderat- ing role of trait emotional intelligence. Social Behavior E Personality: An International Journal, 38(1), 75-86.

Sharabi, M. (2017). The meaning of work dimensions according to organizational status: Does gender matter? Employee Relations, 39(5), 643-659.

Shetach, A., \& Marcus, O. 2014. Team performance management/ : an international journal article information: Team Performance Management: An International Journal, 21(3/4), 181-198. https://doi.org/ http://dx.doi.org/10.1108/13527590810883415.

Shokrkon, H., \& Naami, A. (2009). The relationship of job satisfaction with organizational citizenship behavior and job performance in Ahvaz factory workers. Journal of Education and Psychology, 3(2), 39-52

Steger, M., Frazier, P., Oishi, S., \& Kaler, M. (2006). The meaning in life questionnaire: Assessing the presence of and search for meaning in life. Journal of Counselling Psychology, 53(1), 80-93.

Swaminathan, S., \& Jawahar, P. D. (2013). Job satisfaction as a predictor of organizational citizenship behavior: An empirical study. Global Journal of Business Research, 7(1), 71-80.

Teh, P., \& Sun, H. (2012). Knowledge sharing, job attitudes and organisational citizenship behaviour. Industrial Management E Data Systems, 112(1), 6482.

http:/ / doi.org/10.1108/02635571211193644

Van Dyne, L., Graham, J. W., \& Dienesch, R. M. (1994). Organisational citizenship behaviour. Construct redefinition, measurement and validation. Academy of Management Journal, 37(4), 765-802.

Wan, H. L. 2011. The Role of Leader-Member Exchange in Organisational Justice/ : Organisational Citizenship Behaviour Relationship, 1-17.

Wrzesniewski, A. 2003. Finding positive meaning in work. San Francisco: Berret-Koehler. 